\title{
FACTORS OF ECONOMIC TRANSFORMATION IN SUB-URBAN AREAS OF RAJSHAHI CITY, BANGLADESH
}

\begin{abstract}
Md. Mizanoor Rahman
Department of Geography and Environmental Studies, University of Rajshahi, Rajshahi 6205, Bangladesh. Email: mizan_ra2005@yahoo.com

Abstract: Urbanization of Bangladesh is developed by the natural growth of city, sub-urban growth, sub-urban transformation to urban area, and attaining new urban centers. Accordingly, growth of major urban centers depends on natural growth of city, suburban growth, sub-urban transformation and change in development level of sub-urban areas. As a result, the economy of those areas changes over time and the changes are controlled by a number of factors that playing increasingly dominated roles on the urban as well as national economy of Bangladesh. In the research an attempt has been made to identify the factors that have been influencing the economic transformation, the consequences of transformation in the area, and adopted governmental policies and programmes to develop them. Necessary data and information have collected from both primary and secondary sources for the study, and to analysis and represent of collected data quantitative analysis and mapping techniques have been applied. The research findings indicate that the change in economic setting of those areas in term of occupation, income, expenditure, land use, agricultural practices, infrastructure and facilities and so on is dependent on a set of factors such as distance, market demand, growth center, land availability and land value, employment opportunity, facilities and governmental development policies and programmes.
\end{abstract}

Key words: Economic transformation, factors of economic transformation, sub-urban areas

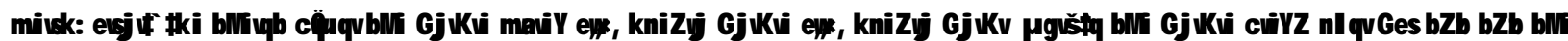

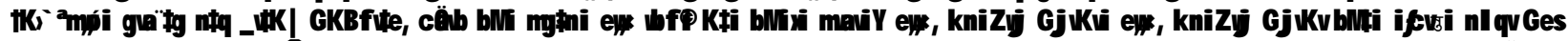

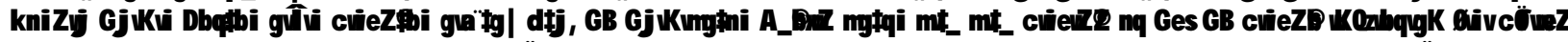

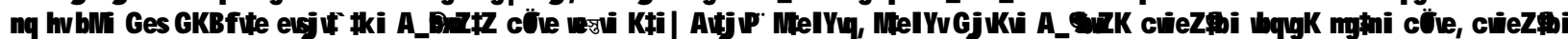

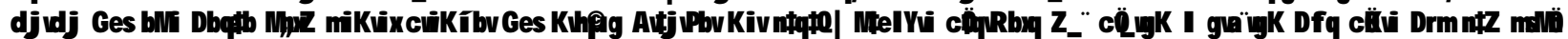

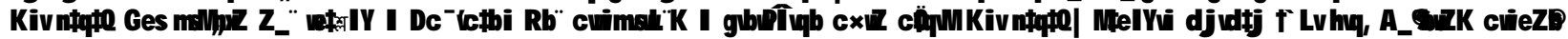

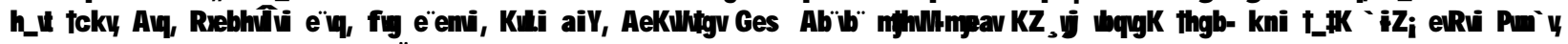

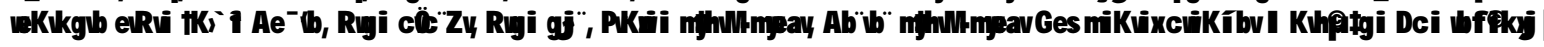

\section{Introduction}

The urban population has been growing consistently at a higher rate than the rural population and in this respect the developing countries are in ahead in recent time. The world urban population rose from 13\% (220 million) in 1900 , to $29 \%$ (732 million) in 1950 , and to 49\% (3.2 billion) in 2005 (United Nations 2005). It is predicted that by 2030, around 61 percent of the world population will live in urban areas, at which time the world urban population will be approaching 5 billion out of 8.1 billion world population. Bangladesh has been experiencing rapid urbanization after independence in 1971. About 35 million people or a quarter of the population currently live in urban areas, compared to only 8\% during independence (World Bank 2007) and it is estimated that by 2020, about $40 \%$ of the total population will live in urban areas (DFID 2004). Despite a recent decline in overall population growth, the immense rate of rural-urban migration has sustained high urban population growth, which currently stands at 5-6\% per annum, almost twice that of rural areas; and if trends continue, more than half of the population of Bangladesh will be urban by the year 2030 (ADB 2007).
Urban growth of Bangladesh mainly depends on suburban expansion, attaining new urban center through fulfillment of urban criteria and very little on the densification of the core city. A German geographer, $\mathrm{H}$. Louis in 1936, first focused the concept of sub-urban when he contributed himself to the research of Berlin's urban structure and he named the sub-urban area as “stadtranzonen”. From the beginning of the 20th century the term periphery has been subjected to a lot of discussions. Whatever may be the designation, conceptually, fringe is related to the growth of cities that lies immediately outside the designated urbanizable limits and has strong interaction with present city and bears an urban reflection of on the physical, occupational and demographic characteristics (Sinha 1997). Recently Gey van Oort (2008) showed that the urban area increases with the course of time and gradually expands towards the rural area. But the inbetween area of urban and rural, which neither rural nor urban but holds both urban and rural characteristics, is called rural-urban fringe or peri-urban area, which stays on continuous transforming zone from rural area to urban area. As a result, economy of the area is being changed gradually is known as economic 
transformation. Economic transformation can be defined as a process that makes changes the relative contribution of economic sector to GDP and employment over time. This process emerges through two main directions: first, reallocation of factors of production from less productive sectors to more productive ones; and second, diversification of the economy away from primary commodity sectors (agriculture and others) into industry and services (Berthelemy and Soderling 2001).

According to DFID, most of the urban centers of Bangladesh are small; having several peri-urban issues where agricultural activates still main economic activities. Rajshahi is very much in peri-urban expansion and densification of the core city situation with rapid population growth and functional expansion, which brings economic transformation in the urban area as well as in the peri-urban area. Keeping the views in mind, the aims of this research were to explore the factors of economic transformation and their influence on the transforming process of the area to: (a) find out the factors of economic transformation of sub-urban areas; (b) analyze the consequences of economic transformation in the study area; and (c) recommend strategies for the development of the area.

\section{Materials and Methods}

For the study both descriptive and explorative methods have been applied to fulfill the requirement of the objectives. An attempt is made in explorative part to explore the factors that influencing the economic transformation of the area while in descriptive part consequences of economic transformation were described. However, three villages from three sub-urban areas were selected as representative of sub-urban villages through random sampling method. The sampled villages are Kasiadanga, Aliganj and Kharkharia. In the study both primary and secondary data were used for analyzing the situation. Primary data was collected through reconnaissance survey, household questionnaire survey, key informants interview, group discussion and field observation while secondary data was collected from several governmental and non-governmental offices. For analyzing collected data quantitative analysis like tabulation, graphic presentation, bivariate correlation and mapping analysis techniques have been applied.

\section{Study area}

The focused area for the study is sub-urban areas of Rajshahi City Corporation (RCC) consist of 13 villages (Fig. 1) with $16.40 \mathrm{~km}^{2}$, which is almost one-third of RCC area. The villages are situated in three distinct areas such as in south-west sub-urban and two different locations in north-west and north-east sub-urban areas. The south-west sub-urban area encompasses of five villages while the north-west peri-urban area contains three villages and north-east sub-urban area includes five villages. However, the total sub-urban area is located under Paba Upazila administrative unit. The outer side of the study area is bounded over by the rural area of Paba Upazila whereas inner side is bounded over by the RCC.

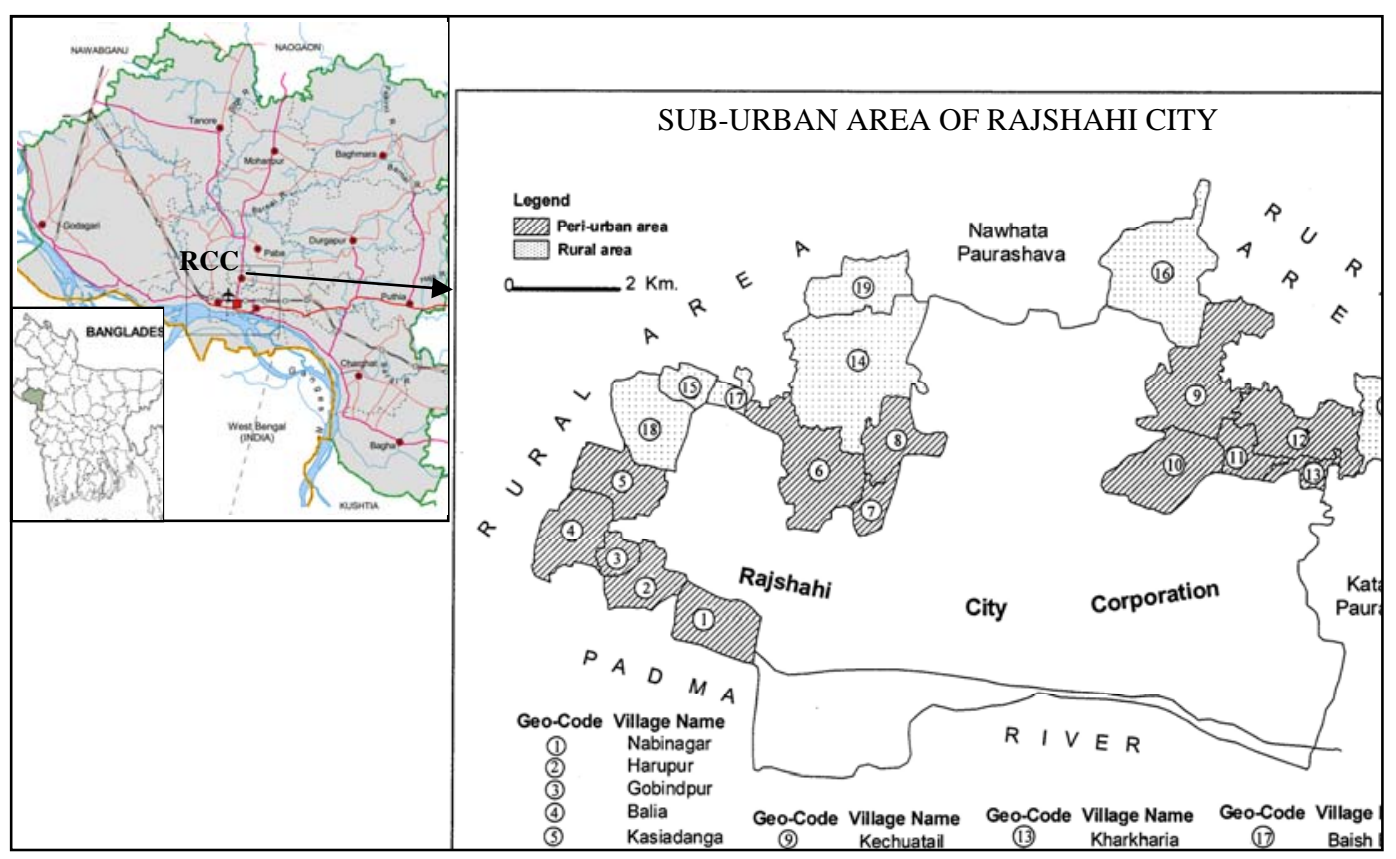

Fig. 1. Map of the study area 


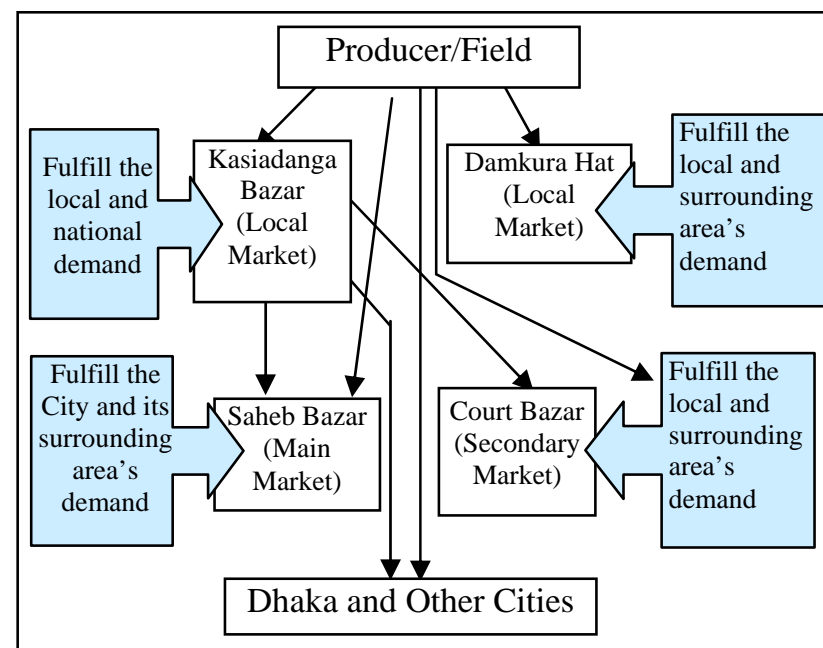

Fig. 2. Marketing channel of Kasiadanga village

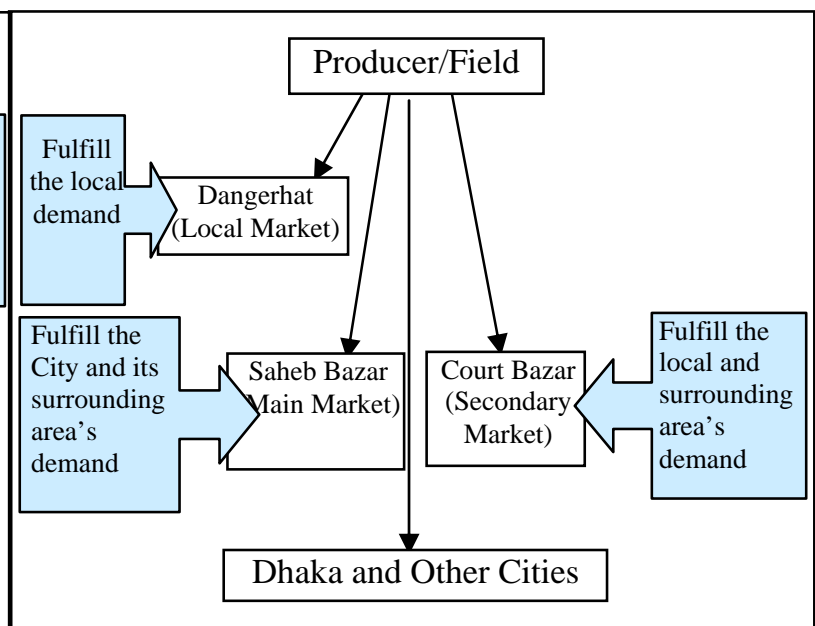

Fig. 3. Marketing channel of Aliganj Village

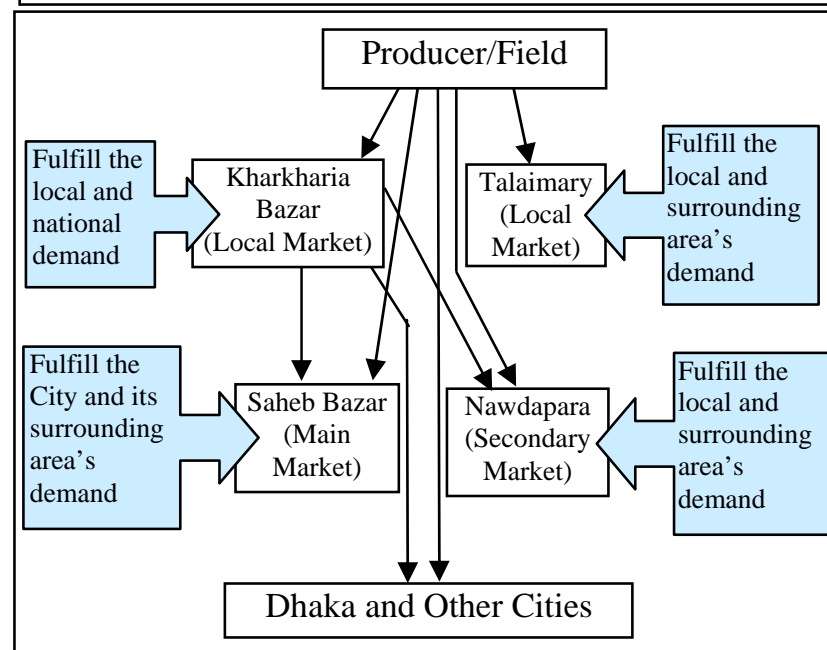

Fig. 4. Marketing channel of Kharkharia village

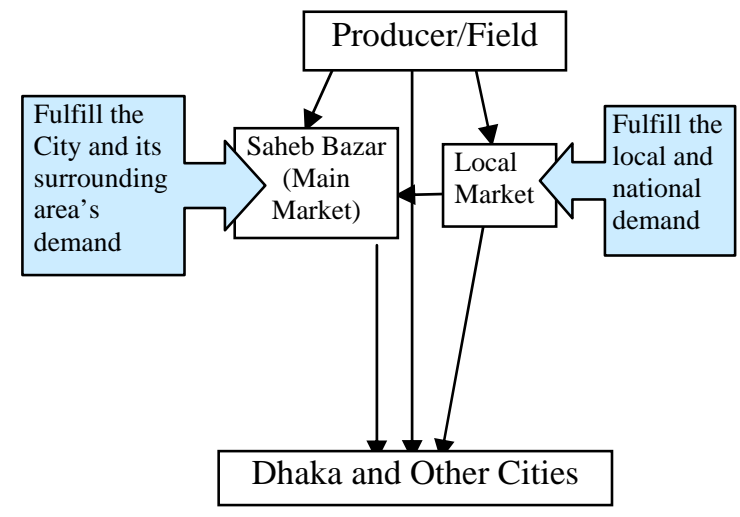

Fig. 5. Marketing channel of Sub-urban Area

1. Marketing channels: Shorter distances as firms and workers migrate closer to economic opportunities (WDR 2009). Delivery price directly depends on distance between production areas to delivery centers because of transportation cost is proportionate to the distance (Von Thunen 1826). A number of market centers have created suitable marketing network (Figs. 2-5) that increases the accessibility of all type of products in RCC and its sub-urban as well as the surrounding areas. During field survey, it is observed that within 7 kilometers range each of the sub-urban villages has link with one more market centers and the markets are facilitated by both retail and wholesale opportunities. 
Table 1. Number of market centres according to distance from village

\begin{tabular}{|l|c|c|c|c|}
\hline $\begin{array}{c}\text { Name of } \\
\text { villages }\end{array}$ & $\begin{array}{c}\text { Within } 1 \\
\mathrm{Km} .\end{array}$ & $1-3 \mathrm{Km}$. & $\begin{array}{c}3-5 \\
\mathrm{Km} .\end{array}$ & $\begin{array}{c}5-7 \\
\mathrm{Km} .\end{array}$ \\
\hline Kasiadanga & 1 & 2 & 0 & 1 \\
\hline Aliganj & 0 & 2 & 1 & 1 \\
\hline Kharkharia & 1 & 0 & 2 & 1 \\
\hline
\end{tabular}

Data source: Field Survey 2008

Table 1 shows that Kasiadanga has own market centre within $1 \mathrm{~km}$. At the same time, it is well connected with Damkura hat (3 Km.), Court Bazaar (3 km) and Shaheb Bazar (6 km). Accordingly, distance from Aliganj to both Dangerhat and Court Bazar is $3 \mathrm{~km}$, and Saheb Bazar is $5 \mathrm{~km}$. On the other hand, Kharkharia has own market centre and well connected with the main market centre (Saheb Bazar) by road. However, these market centres are well connected with the other parts of country offers an apposite marketing channel for each village, which has direct and indirect impact on the change of agricultural land use, cropping pattern as well as agricultural production.

a) Change in agricultural land use and cropping pattern: Fig. 6 demonstrates the cultivated area under different agricultural types and table 2 shows the annual change of cultivated land under same agricultural types. Crops land in the sub-urban area was 92.24 per cent in 1991, which became $85.09 \%$ in 2001 and $69.52 \%$ in 2008. During 1991-2001 crop land was reduced yearly by $1.28 \%$ while during $2001-2008$ it was reduced yearly by $1.62 \%$. The area under vegetables \& fruits cultivation was $63.33 \%$ of the total cultivated land in 1991, 72.71\% in 2001 and $102.73 \%$ in 2008. During $1991-2001$ the yearly increasing rate was $0.94 \%$, while during 2001-2008 it was $3.68 \%$. It is remarkable that the poultry practice was introduced after 2001 in the area and the change is not so much high as compare to other types of agriculture. Moreover, the growth of poultry is limited due to lack of capital needed to investment and as well as governmental support. On the other hand, change is not found in aquaculture practices in all three villages due to unchanged situation of water bodies during the study period.
Table 2. Agricultural land use change (percentage per year) during 1991-2008.

\begin{tabular}{|l|c|c|c|c|}
\hline Area & Period & $\begin{array}{c}\text { Crop } \\
\text { land }\end{array}$ & Poultry & $\begin{array}{c}\text { Vegetables and } \\
\text { fruits }\end{array}$ \\
\hline $\begin{array}{l}\text { Sub-urban } \\
\text { areas of RCC } \\
\text { (Aggregated) }\end{array}$ & $\begin{array}{c}1991- \\
2001\end{array}$ & -1.28 & 0 & +0.94 \\
\cline { 2 - 5 } & $2001-$ & & +0.15 & +3.70 \\
\hline
\end{tabular}

Agricultural Office, Paba, 2009

Furthermore, it is observed that the change in recent time is higher than that of the previous time for all types of agriculture. In the study area vegetables include potato, brinjal, cabbage, cauliflower, tomato etc in both summer and winter season and fruits encompass mango, banana, guava, watermelon, lemon etc. Fig 7 demonstrates the total cultivated land under vegetables and fruits. It is also observed that vegetables were occupied more land as compare to fruits in all three villages during the study time.

In 1991, the vegetables land was $43.2 \%$ of the total agricultural land that has become $51.94 \%$ in 2001 and $78.33 \%$ in $2008 \%$. Furthermore, it is clearly indicated that vegetables land has become almost double during last 18 years. On the other hand, a little positive change was seen in the fruits cultivation area during study period. In addition, figure 7 also indicates that the area under fruits cultivation has been increased, but the change and occupied land of fruits both are not higher as compare to vegetables.

b) Change in agricultural production: Collected data analysis (Table 3 ) shows that production of vegetables and fruits has been increased while cereal and aquaculture has been decreased gradually due to changing situation of demand. Correlation result (Table 5) shows that the productions of all products are dependent on market demand significantly.

2. Growth of market centres: In the perspective of agricultural change within urban fringe the role of farmers group in diffusion process have led to the clustering of certain types of agricultural activities and forms of market (Bryant and Johnston, 1992). Moreover, under the growth centre development programme, government has developed the existing important hats and bazars into efficient and important market centres through improvement of the 
infrastructures. Through those bazars, hats and growth centers agricultural products of the area are being marketed and traded to Dhaka and other regions where there is demand for them (RDA, 2004). The growth centers and hats offer to farmers demand of specific agro-product that have in the market. This demand influences farmers in decision making to select the suitable crops for the specific season, which brings change in cropping pattern as well as agricultural pattern directly and economic change indirectly in the area

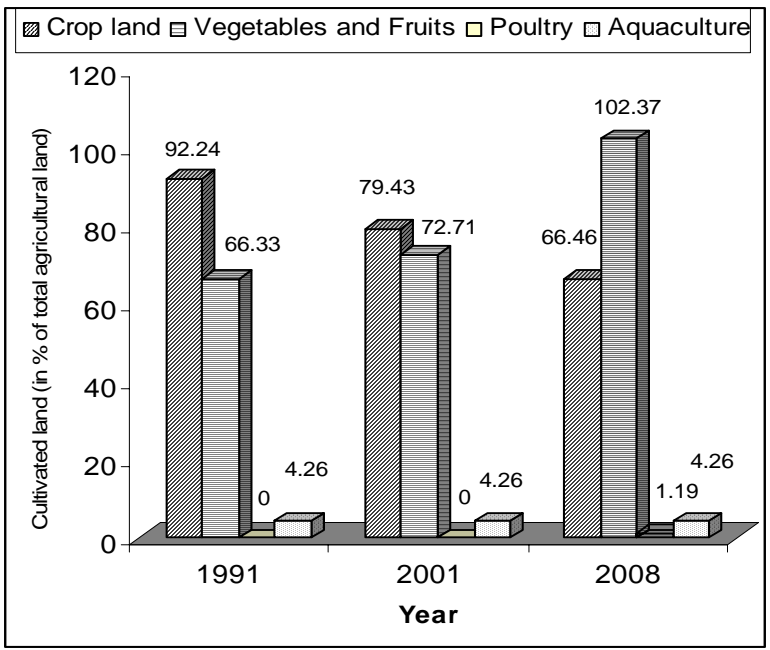

Fig. 6 Cultivated land under different crops during 1991-2008 (Cropping intensity has been considered to calculate the agricultural land use)

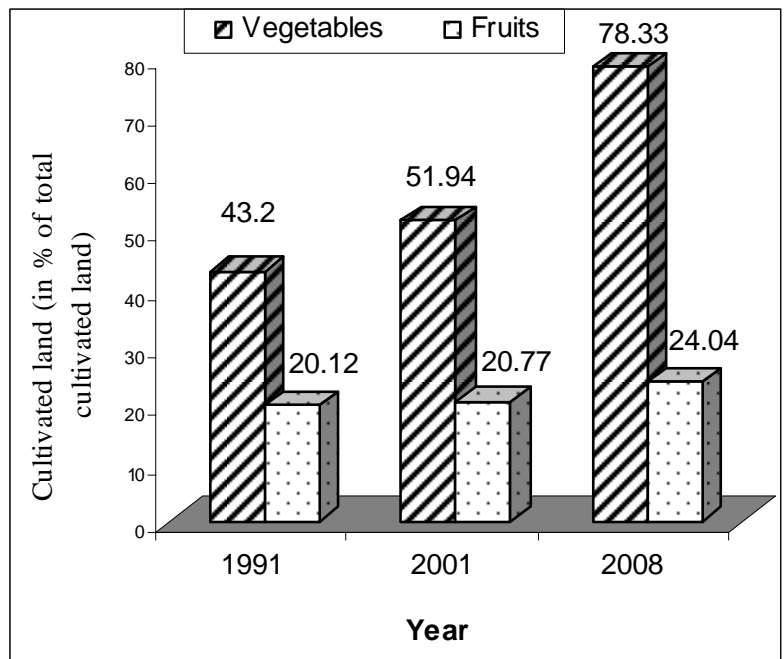

Fig. 7 Cultivated land under different crops during 1991-2008 (Cropping intensity has been considered to calculate the agricultural land use)
Table 3. Major agricultural production (\%) during 1991-2008

\begin{tabular}{|l|c|c|c|c|c|c|}
\hline Area & Year & Cereal & $\begin{array}{c}\text { Vegeta } \\
\text { bles }\end{array}$ & Fruits & $\begin{array}{c}\text { Aquacu } \\
\text { lture }\end{array}$ & Other \\
\hline $\begin{array}{l}\text { Sub- } \\
\text { urban } \\
\text { area of } \\
\begin{array}{l}\text { RCC } \\
\text { (aggreg } \\
\text { ated) }\end{array}\end{array}$ & 1991 & 19.43 & 72.35 & 3.37 & 1.07 & 3.79 \\
\cline { 2 - 7 } & 2008 & 14.68 & 80.66 & 1.83 & 0.78 & 2.05 \\
\hline
\end{tabular}

Data source: Thana Agricultural Office, Paba, 2009

\section{Urban growth centres around Rajshahi City}

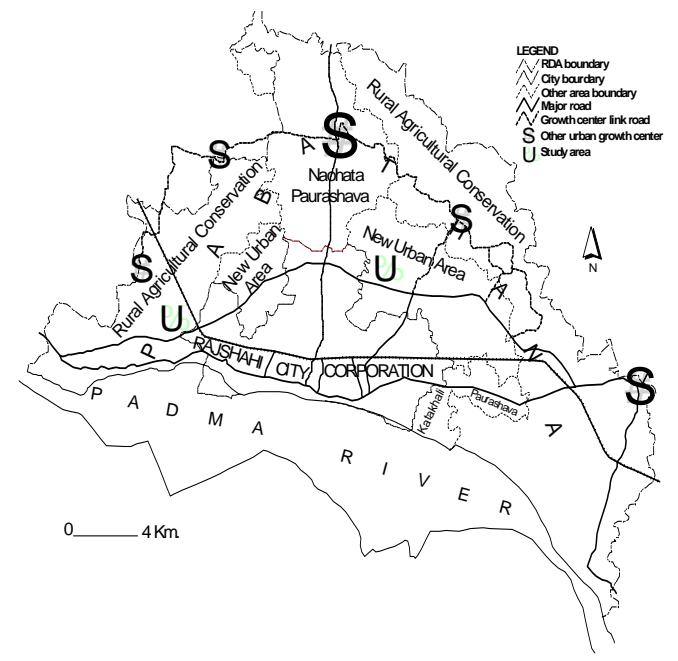

Fig 8. Map of urban growth centres around Rajshahi City (Source: Rajshahi Development Authority, RDA)

3. Market demand: Land of sub-urban area uses for both agricultural and non-agricultural purposes and the agriculture of this area is operated to meet up the food demand of itself and RCC area as well as country. In the table 4 , an endeavor is made to show the change in demand of different crops in sub-urban and Rajshahi City Corporation (RCC) area from year to year. In RCC, the total consumption of food was 100719 metric ton in 1991 and 171629 metric ton in 2001; and during this period food demand has been increased by $70.46 \%$. Likewise, variation in demand was found in different agricultural productions, which influences the agricultural pattern of the area. The demand of cereals was $48.51 \%$ in 2001 which was $50.16 \%$ in 1991; vegetables was $22.55 \%$ in 2001 which was $22.29 \%$ in 1991; fruits was $4.09 \%$ in 2001 which was $2.49 \%$ in 1991; and fish was $4.70 \%$ in 2001 which was $5.09 \%$ in 
1991 in RCC area. Similar trend was seen in the food demand of sub-urban areas of RCC. In sub-urban areas, the cereal demand was 53.09\%, 54.99\%, and 49.53\% in 1991, 2001 and 2008 respectively; vegetables demand was $22.09 \%, 21.90 \%$ and $23.24 \%$ in 1991, 2001 and 2008 respectively; fruits demand was 2.77\%, 3.17\%, and 3.40\% in 1991, 2001 and 2008 respectively; and fish demand was $4.24 \%, 4.29 \%$ and $4.44 \%$ in 1991 , 2001 and 2008 respectively. So, the above discussion indicates that demand of all the agricultural products has been increased except cereal. Moreover, correlation test result (Table 5) shows that the relation between demand and production of different agro-products is positive and highly significant. So, it can be said that cropping pattern as well as production of different crops is influenced by the demand factor.
Table 4. Food demand (\%) of RCC and its sub-urban areas

\begin{tabular}{|l|c|c|c|c|c|}
\hline \multirow{2}{*}{ Food Items } & \multicolumn{2}{|c|}{ RCC } & \multicolumn{3}{c|}{ Sub-urban areas } \\
\cline { 2 - 6 } & 1991 & 2001 & 1991 & 2001 & 2008 \\
\hline Cereals & 50.16 & 48.51 & 53.09 & 54.55 & 49.53 \\
\hline Vegetables & 22.29 & 22.55 & 22.09 & 21.90 & 23.24 \\
\hline Fruits & 2.49 & 4.09 & 2.77 & 3.17 & 3.40 \\
\hline Fish & 5.09 & 4.70 & 4.24 & 4.29 & 4.44 \\
\hline Others & 19.96 & 20.16 & 17.80 & 16.13 & 19.39 \\
\hline Total & 100 & 100 & 100 & 100 & 100 \\
\hline
\end{tabular}

Data sources: BBS 1995, BBS 2003 and Field Survey 2009

Table 5. Co-efficient of correlation (r) values between demand and production of different agricultural products

\begin{tabular}{|c|c|c|c|c|c|c|c|}
\hline & & $\begin{array}{c}\text { Cereal } \\
\text { Production }\end{array}$ & $\begin{array}{l}\text { Vegetables } \\
\text { Production }\end{array}$ & $\begin{array}{c}\text { Fruits } \\
\text { Production }\end{array}$ & $\begin{array}{c}\text { Fish } \\
\text { Production }\end{array}$ & Total Production & Remarks \\
\hline \multirow{2}{*}{\begin{tabular}{|l|} 
Cereal \\
Demand
\end{tabular}} & Corr. Value & $.946(* *)$ & & & & & \multirow{10}{*}{$\begin{array}{c}\text { Correlation between } \\
\text { demand and production } \\
\text { of different } \\
\text { agricultural products } \\
\text { are positive and highly } \\
\text { significant }\end{array}$} \\
\hline & Sig. Value & .000 & & & & & \\
\hline \multirow{2}{*}{$\begin{array}{l}\text { Vegetables } \\
\text { demand }\end{array}$} & Corr. Value & & $.994(* *)$ & & & & \\
\hline & Sig. Value & & .000 & & & & \\
\hline \multirow{2}{*}{$\begin{array}{l}\text { Fruits } \\
\text { demand }\end{array}$} & Corr. Value & & & $.916(* *)$ & & & \\
\hline & Sig. Value & & & .000 & & & \\
\hline \multirow{2}{*}{$\begin{array}{l}\text { Fish } \\
\text { demand }\end{array}$} & Corr. Value & & & & $.917(* *)$ & & \\
\hline & Sig. Value & & & & .000 & & \\
\hline \multirow{2}{*}{\begin{tabular}{|l|} 
Total \\
demand
\end{tabular}} & Corr. Value & & & & & $.998(* *)$ & \\
\hline & Sig. Value & & & & & .000 & \\
\hline
\end{tabular}

Moreover, increasing demand of land for different uses has brought change in land use pattern. Table 6 illustrates that land under agriculture use is decreasing due to increasing demand of land for housing, commercial and to some extent for industrial uses. In 1991, 2001 and 2008 the agricultural land was 62.11\%, $59.42 \%$ and $55.51 \%$ of total land respectively; land under housing was $9.28 \%, 11.87 \%$ and $15.69 \%$ of total land respectively; land under industry was $0 \%, .01 \%$

Table 6. Land use pattern (\%) during 1991-2008 and .01\% respectively; and commercial land was .03\%, $.04 \%$ and $.06 \%$ respectively. During 1991-2001 the agricultural land was decreased by $.27 \%$ per year while during 2001-2008 it is decreased by .49\% per year. But the housing land was increased by .26\% per year during 1991 to 2001 and by .47\% per year during 2001-2008. Though, the change in commercial and other land uses is not so remarkable in the area.

\begin{tabular}{|c|c|c|c|c|c|c|c|c|c|c|c|c|c|c|c|}
\hline Area & \multicolumn{3}{|c|}{ Agriculture } & \multicolumn{3}{|c|}{ Housing } & \multicolumn{3}{|c|}{ Road and Railway } & \multicolumn{3}{|c|}{ Industry } & \multicolumn{3}{|c|}{ Commercial } \\
\hline Sub-urban area & 1991 & 2001 & 2008 & 1991 & 2001 & 2008 & 1991 & 2001 & 2008 & 1991 & 2001 & 2008 & 1991 & 2001 & 2008 \\
\hline $\begin{array}{l}\text { of RCC } \\
\text { /Aggregate }\end{array}$ & 62.11 & 59.42 & 55.51 & 9.28 & 11.87 & 15.69 & .53 & .53 & .53 & 0 & .01 & .01 & .03 & .04 & .06 \\
\hline
\end{tabular}

Sources: Tohosil Office of Kasiadanga and Kharkharia, Rajshahi Development Authority (RDA) and SPARRSO 
4. Land availability, price and investment opportunity: Field observation result shows that availability of getting large-scale land in RCC is very limited and costly as compare to sub-urban areas. As a result, investors prefer to procure land in peri-urban area in order to use for agricultural and commercial purpose. For example, Aman group has occupied a large area for seed breeding center in Lalitahar village (sub-urban area of Rajshahi city) and Bishal group has bought 3 acres land for building commercial center in Kharkharia village (sub-urban area of Rajshahi city). Besides, land is safe investment area gives more return within short time, and due to potentiality investors have great interest to occupy land in the sub-urban area. Moreover, people those have small land in urban area have very limited scope to serve their purpose tend to sale and buy more land in suburban areas. For example, in Aliganj, a number of families have migrated in due to get opportunity of having more land. On the other hand, migrant from rural area those have less ability to reside in urban area, live in sub-urban areas for low living cost. As a result change in land use pattern and its associated aspects have brought change in economic process of the area.

5. Employment opportunity: Most of the urban people are economic migrants coming from the rural areas and contribute to large informal sector (Rahman 2000). Due to shorter distance, the sub-urban dwellers have better opportunity to be appointed in informal sectors of suburban and RCC area. Survey result shows that 3.31\% people of sub-urban areas service in RCC area. For the purpose people easily go to RCC for serving at the morning and come back at the evening. Besides, the area is great source of employment in both agricultural and non-agricultural sectors providing a large number of people, which has increased per capita income and expenditure of the dwellers (figure 10). This opportunity attracts people to live here and also to migrate from other areas (both rural and urban) that contribute to the economic transformation of the area.

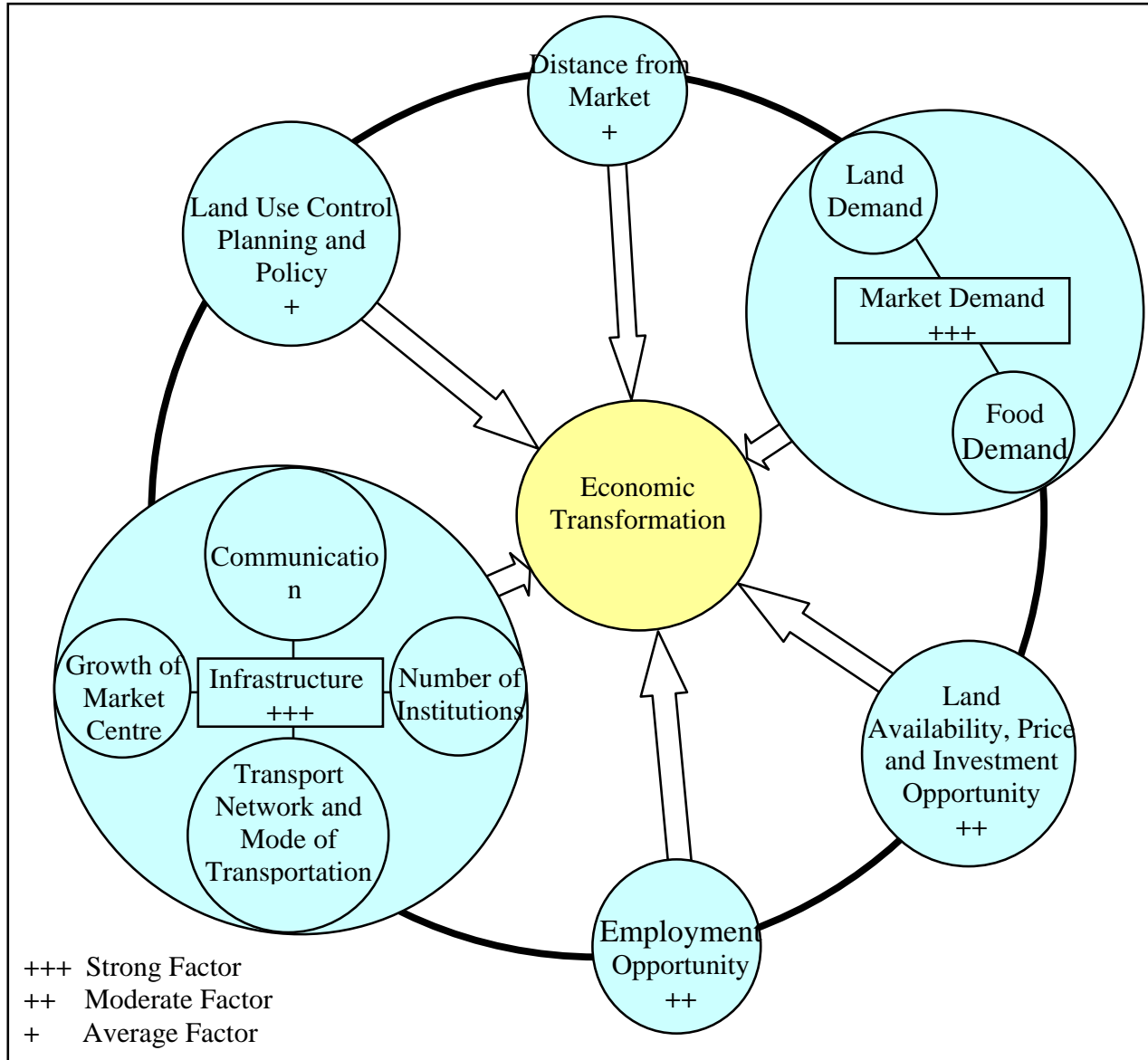

Fig. 9 Factors influencing economic transformation in sub-urban 
6. Infrastructure: The growth directions of Rajshahi City followed by development of road network and a major direction has taken place along the RajshahiNaogaon Road. Growth to northern direction also is influenced by Cantonment, Upashahar Housing Estate, BCISC Industrial Estate, followed by BDR Head Quarter, Postal Academy, Rajshahi Airport and some industries development. Recently, development of RDA Head Office, RDA commercial and industrial projects, Women Polytechnic, Forest Training Institute, College of Physical Education, Inter District Bus Terminal, Truck Terminal, New City Bypass, Market Centers etc. further accentuated the possibility of northward development trend of the city. Moreover, it is observed from the field survey that infrastructures such as educational institutes, market centres, NGOs office, brick made housing, transport network and transportations, electricity, communications etc in terms of number and quality have been increased in the study area that has brought more employment opportunity to the sectors in the one hand and on the other hand that has offered more suitable environment to play the economic activities. For example, owing to better transport network and transportation, mobilization of products and threshold distance has been increased which impacts directly on the economy of the area.

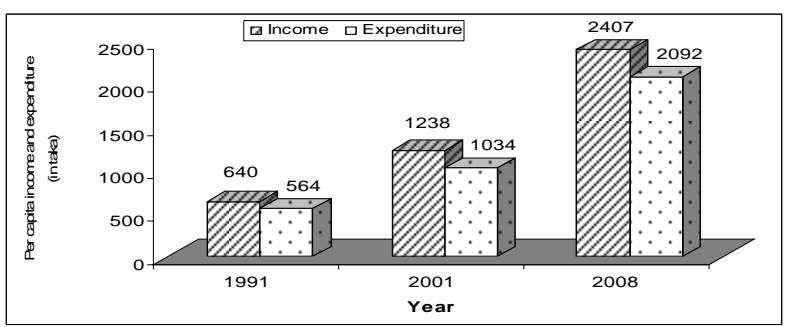

Fig. 10 Per capita income and expenditure during 1991-2008

7. Availability of urban facilities in the peri-urban areas: During the field survey, it was observed that urban facilities such as electricity, availability of fuels for cooking purpose, mobile phone, shopping facilities, dish cable network, education, medicine, service centre, restaurant, transportations etc are available with low cost as compared to urban area, augment suitability of the area and pull low income people to migrate to peri-urban area that brings change in population composition and indirectly economic transform of the area.

8. Land use control planning and policy: Sub-urban area of Rajshahi City is the extended developed area of RCC. The RCC and its sorrounding area has been demarcated into 25 Spatial Planning Zone (SPZ) on the basis of computable land use and social characteristics, and SPZ-4, SPZ-6, SPZ-7, SPZ-9, SPZ-12 and SPZ-12 are include in sub-urban areas. The RDA emphasizes main two issues such as land use planning and implementation, and infrastructures development as well as availability of facilities for developing the area. According to land use planning the SPZ-6 and SPZ-7 are conserved for residential area and SPZ-12 is for brickfield. With the increasing demand of land, new land conservation will continue in the sub-urban area. Besides, the proposed plan outline includes development of town centers and five new light industrial state those will be in the northern part of the existing city and in proposed new urban area; and drainage, sewerage, water and electricity, road network, housing, reaction-open space will be developed gradually by 2024, and RDA, RCC, PDP, DPHE, LGED and BTCL are responsible institutes to implement the plans (RDA, 2004). The ongoing Master Plans of RDA increases the potentiality of the area and playing vital role in the over all change as well as economic change of the area.

\section{Recommendations and Conclusion}

Growth and development of sub-urban areas of RCC are haphazard and unplanned that have reduced the actual competency and return of the area. Though the areas are under the RDA jurisdiction and have some urban facilities but these are very much limited and insufficient for dwellers. This is how, it is utmost needed to implement the existing development plan of Rajshahi Development Authority in order to enhance road network, develop housing facilities, increase urban facilities like electricity, drainage, telecommunication, dish cable, water supply, health facilities, education etc. as well as enhance marketing facilities and channel to secure the price of products, and industrial development. Moreover, the area has proximity to be urban in near future so that integration between the development work of urban and sub-urban areas may bring better economic opportunity and more urban facilities for the dwellers as well as better development of the areas.

\section{References}

Asian Development Bank (ADB). 2007. Involving the urban poor in municipal governance in Bangladesh. NPRSPRF.

Berthelemy J and Soderling L. 2001, The Role of Capital Accumulation, Adjustment and Structural Change for Economic Take-off: Empirical Evidence from African Growth Episodes. World Development 29(2): 323-343.

BBS (Bangladesh Bureau of Statistics) 1995. Report of the Household Income and Expenditure Survey, Dhaka. 
Bangladesh Bureau of Statistics (BBS) 2003. Report of the Household Income and Expenditure Survey, Dhaka.

Bryant CR. 1995. The role of local actors in transforming the urban fringe. J. Rural Studies 3: 255-267.

Bryant CR and Johnston TRR 1992. Agriculture in the City's Countryside, University of Toronto Press, Toronto.

DFID 2004. Rural and Urban Development Case StudyBangladesh. DFID Country Report, Oxford Policy Management.

Louis H. 1936. "Die geographische Gliederung von GrossBerlin" [The geographical structure of Greater Berlin], in Länderkundliche Forschung: Krebs-Festschrift by H Louis and W Panzer, Engelhorn Stuttgart, pp. 146171.

Oort G van. 2008. Rural-urban fringes: Another approach. In: New Perspectives in Urban Geography (ed. Singh SB), M D Publications Pvt. Ltd., New Delhi, India.

Rahman MM. 2000, Bastee eviction and housing rights: A case of Dhaka, Bangladesh, Habitat International 25(1): p. 49.
RDA, 2004, Rajshahi Metropolitan Development Plan (20042024), Rajshahi, Bangladesh.

Sinha RLP. 1997. Urban fringe: Approaches and policy options. ITPI Journal 15(1-4): 167-170.

UN (United Nations) 2005. Responding to the Challenges of an Urbanizing World. UN-HABITAT Annual Report, United Nations Human Settlements Programme. ..pp.

Von Thunen, 1826, “Von Thunen's Isolated State” In Agricultural Geography by Munton, R.J.C. and Morgan, W.B., Mathuen \& Co. Ltd. pp. 79-88.

World Bank 2007. Bangladesh: Strategy for Sustained Growth. Bangladesh Development Series...pp.

World Development 2009. http://econ.worldbank.org/wbsite/external/extdec/extre search/extwdrs/extwdr2009/0,,menupk:4231145 page pk:64167702 pipk:64167676 thesitepk:4231059,00.ht ml?cid=gs_decwdr09_16

Manuscript received on23 October and revised on 7 December 2010. 